Review

\title{
A review on photocatalysis in antibiotic wastewater: Pollutant degradation and hydrogen production
}

\author{
Zhidong Wei a,b, Junying Liu $\mathrm{a,b}$, Wenfeng Shangguan $\mathrm{a}, \mathrm{b}, *$ \\ a Research Center for Combustion and Environment Technology, Shanghai Jiao Tong University, Shanghai 200240, China \\ b Center of Hydrogen Science, Shanghai Jiao Tong University, Shanghai 200240, China
}

\section{A R T I C L E I N F O}

\section{Article history:}

Received 17 January 2020

Accepted 10 March 2020

Published 5 October 2020

\section{Keywords:}

Photocatalytic

Antibiotics

Degradation

Hydrogen Energy

Thermodynamic

\begin{abstract}
A B S T R A C T
Surveys on antibiotics have become one of the most popular topics in the recent two decades. From 1998 to 2018, more than 5,000 articles concentrated on the research of antibiotic wastewater treatment have been published. Among them, photocatalysis has received much attention due to its green and environmental-friendly properties. In this mini-review, the recent progress of photocatalysis in antibiotic wastewater was summarized, including antibiotics degradation and hydrogen energy conversion. The photocatalysts commonly used were also discussed. It can be mainly classified as $\mathrm{TiO}_{2}$-based materials, sulfides and polymeric carbon nitride-based materials and bismuth-contained materials. Four major types of antibiotics, tetracycline, sulfonamide, $\beta$-lactam and quinolone, were involved. Furthermore, perspectives concentrated on future development and challenges, especially converting antibiotics into hydrogen energy, were also proposed.
\end{abstract}

(C) 2020, Dalian Institute of Chemical Physics, Chinese Academy of Sciences. Published by Elsevier B.V. All rights reserved.

\section{Introduction}

With the rapid development of the drug and medical industry, the consumption of the antibiotics became increase among humans and animals. It could cure lots of diseases timely and then avoided getting more serious sickness [1]. Until to now, there existed various kinds of antibiotic drugs, such as tetracycline [2], sulfonamide, $\beta$-lactam, quinolone and penicillin.

The large demands of the antibiotics prohibited people and animals from the infection of bacteria, therefore saves a lot of lives. However, for the ecosystems and natural environment, the following antibiotic pollution also needs to be paid much attention, which was caused by the discharge procedure. The persistence and difficult to degradation properties of the antibiotics will arise some serious environmental problems besides the severe water pollution, such as the emergence of drug resistance [3]. More seriously, the existence of the antibiotics in the water will be favorable for breeding antibiotic-resistant bacteria, posed threaten to the health of people and the effectiveness of the antibiotic drugs [5]. As a result, a lot of methods, which involves the adsorption, photocatalysis, biodegradation, electrochemical treatment and so on, were applied to tackle the mentioned issues effectively [6]. Photocatalysis technology, which possessed a green, effective, economical and environmentally friendly property, has received much concern from scientists. The solar energy conversion and utilization also boosted photocatalysis became one of the hottest topics among the past decades [7-14].

The application of $\mathrm{TiO}_{2}$ in photocatalysis was popular since it was reported in 1972 [15]. It has a suitable conduction band

\footnotetext{
* Corresponding author. Tel: +86-21-34206020; E-mail: shangguan@sjtu.edu.cn

This work was supported by the National Natural Science Foundation of China (21773153) and the National Key Basic Research and Development Program (2018YFB1502001) for the financial support as well as the funding support from Center of Hydrogen Science, Shanghai Jiao Tong University, China.

DOI: S1872-2067(19)63448-0 | http://www.sciencedirect.com/science/journal/18722067 | Chin. J. Catal., Vol. 41, No. 10, October 2020
} 
and valence band position for both hydrogen production and pollutant degradation. Therefore, in the primary decades, researches were mainly focused on the $\mathrm{TiO}_{2}$ as photocatalysts for antibiotic wastewater degradation [16-20]. Nevertheless, the drawbacks of $\mathrm{TiO}_{2}$, such as the rapid recombination of photocarries, were also limited its industriousness applications. Additionally, it only could be responsible for UV light, which merely accounts for $4 \%$ in the overall solar spectrum. As a conclusion, scholars devoted themselves to explore and design novel photocatalysts to utilize the visible light, which occupied more than $40 \%$ ratio in the overall solar spectrum. Under this circumstance, sulfides, like CdS, have ignited the interests of the scientists [21-25]. Due to the S element contributed to the structure of the valence band, the bandgap was narrow thus could absorb the visible light effectively. However, this also weakened the oxidizing ability of the sulfides compared with the corresponding oxides. Furthermore, the stability also constrained its further applications. In 2009, Wang and co-workers initially reported a novel polymeric material, polymeric carbon nitride (PCN or g- $\mathrm{C}_{3} \mathrm{~N}_{4}$ ), for photocatalytic hydrogen evolution [26]. In the past decade, due to its low cost, high efficiency and visible-light-responsible properties, $\mathrm{g}-\mathrm{C}_{3} \mathrm{~N}_{4}$ has become the hottest materials among photocatalytic field like water splitting, hydrogen evolution, antibiotic wastewater degradation, $\mathrm{CO}_{2}$ reduction. Different from the sulfides, $\mathrm{g}-\mathrm{C}_{3} \mathrm{~N}_{4}$ showed a more stable structure than sulfides [27-32].

Past years have witnessed the development of the bismuth-based materials for photocatalytic hydrogen evolution and pollutants degradation [33,34]. Different from the mentioned three main kinds of photocatalysts, bismuth-based materials, such as $\mathrm{BiVO}_{4}, \mathrm{Bi}_{2} \mathrm{O}_{3}$, have suitable valence band position for visible-light-driven antibiotics degradation. The structure of $\left[\mathrm{Bi}_{2} \mathrm{O}_{2}\right]^{2+}$ was beneficial for the formation of the internal electric field and therefore enhanced the separation efficiency of the photogenerated electrons and holes. This distinctive and superior property made the bismuth-based materials attracting the most extensive attention for photocatalytic antibiotic wastewater removal. For this reason, large of Bi-based photocatalysts appeared with a trend of bamboo shoots after a spring rain.

Recently, the idea of waste to energy has been proposed [35-38]. The wastewater, waste gases and even cellulose were used as the hydrogen sources in these researches. The results showed that photocatalytic hydrogen could be obtained with simultaneous waste removed. The waste in these studies played the role of sacrificial reagents, which provided a possible substitution for the traditional sacrificial reagents like methanol, ethanol. Similarly, antibiotic wastewater also could be used for hydrogen evolution. There were a few studies have reported the relative development of photocatalytic hydrogen evolution with simultaneous antibiotic wastewater degradation [39-44].

This review concentrated on the photocatalysis in antibiotic wastewater, including the degradation and hydrogen energy production. Furthermore, it also proposed some perspectives on the challenges and further development in the mentioned area.

\section{Fundamental basics of photocatalytic hydrogen evolution and antibiotics degradation}

The procedure of photocatalytic hydrogen and degradation can be schematically described in Fig. 1 . The whole procedure can be divided into three parts: (I) With the irradiation of the incident light, the electrons and holes will be produced in the bulk phase; (II) the photogenerated electrons and holes will migrate to the surface of the photocatalysts, a part of carries will be recombined in process; (III) the photoelectrons will take part in the reduction reaction, like the evolution of hydrogen and $\cdot \mathrm{OH}$. Simultaneously, the holes will take part in the oxidation reaction.

To achieve high efficiency of photocatalytic pollutant degradation and hydrogen degradation, there also some key points in this procedure. At first, the energy of irradiation light should be higher than the band gap of the photocatalyst. Otherwise, the photocatalyst will not absorb the irradiation light and further being induced to produce photocarriers. Secondly, the conduction band of the photocatalysts should afford the demands of hydrogen evolution or superoxide radical generation thermodynamically, which is 0 and $-0.046 \mathrm{eV}$ (vs. NHE, $\mathrm{pH}=0$ ), respectively. At last, similarly, the position of the valence band should be higher than the oxidation position of the pollutant, like antibiotics. More importantly, the $\cdot \mathrm{OH}$ radicals played an important role in contaminates degradation and the production of $\cdot \mathrm{OH}$ mainly originated from two pathways, one is from multistep reduction by photoelectrons as mentioned above, the other is the holes oxidize water $\left(\mathrm{OH}^{-}\right)$. The key issue of this mechanism also involves the thermodynamic demand, which requires the $\mathrm{VB}$ position should be more positive than $2.38 \mathrm{eV}$ (vs. NHE, $\mathrm{pH}=0$ ). That also explained the importance of producing superoxide radical. If the photocatalysts could not oxidize water $\left(\mathrm{OH}^{-}\right)$to produce $\cdot \mathrm{OH}$, the multistep reduction by photoelectrons to generate superoxide radical will provide another possible method to produce $\cdot \mathrm{OH}$ radicals. It will first initiate by $\mathrm{e}^{-}$react with $\mathrm{O}_{2}$ to produce $\cdot \mathrm{O}_{2}{ }^{-}$, then the $\cdot \mathrm{O}_{2}$ - will combine with $\mathrm{H}^{+}$to generate $\cdot \mathrm{HO}_{2}$. Therefore, the $\mathrm{H}_{2} \mathrm{O}_{2}$ as the intermediate products will be produced. At last, $\cdot \mathrm{OH}$ radicals can be evolved through the dissociation of the $\mathrm{H}_{2} \mathrm{O}_{2}$.

\section{Photocatalytic degradation of antibiotic wastewater}

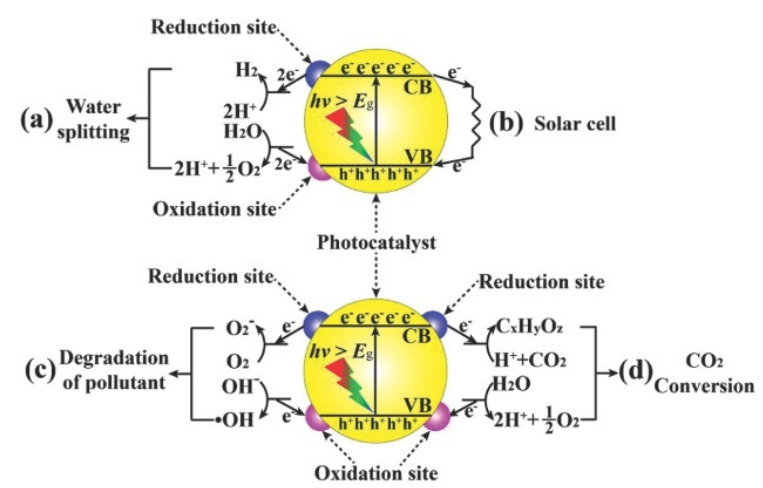

Fig. 1. Fundamental basics of photocatalysis. Reprinted with permission from Ref. [7] Copyright 2014, Wiley-VCH. 
Due to the demands from the thermodynamics of photocatalytic degradation, the selection of photocatalysts plays an important role. Different materials have different CB and VB position, which will exhibit different performances in photocatalysis. Past several years have witnessed the exploration of photocatalytic antibiotic wastewater degradation. Simultaneously, the materials also experienced a crucial development process. As a conclusion, the materials can be classified into four types: $\mathrm{TiO}_{2}$, sulfides, polymeric carbon nitride and bismuth-based photocatalysts. Furthermore, five kinds of antibiotics, tetracycline, sulfonamide, $\beta$-lactam, quinolone and penicillin, were studied as the model antibiotic wastewater normally.

\section{1. $\mathrm{TiO}_{2}$}

$\mathrm{TiO}_{2}$ has gained more attention since it has been reported in photocatalysis [15]. The superior redox ability made it to be the most popular photocatalyst in the primary decades. The applications involved much researches filed, like hydrogen evolution, pollutant degradation. Correspondingly, in the photocatalytic antibiotic wastewater degradation, $\mathrm{TiO}_{2}$ also ignited the interests of the scholars. It can be used for many kinds of antibiotic wastewater purification. Palominos and co-workers reported that the photocatalytic oxidation of the antibiotic tetracycline (TC) can be fulfilled via the $\mathrm{TiO}_{2}$ under simulated solar light [16]. The degradation efficiency was higher than $90 \%$ after being calculated. There were also similar studies focused on the photocatalytic tetracycline wastewater degradation via $\mathrm{TiO}_{2}$ [45-79]. Besides in the tetracycline systems, $\mathrm{TiO}_{2}$ also exhibited an outstanding performance in sulfonamide, $\beta$-lactam and quinolone antibiotic wastewater degradation. For example, Beltran and co-workers found that $\mathrm{TiO}_{2}$ could remove the sulfamethoxazole efficiently via an $\mathrm{O}_{3} / \mathrm{O}_{2}$ assistant method. As a result, 93\% TOC removal could be reached [18]. Amoxicillin, ampicillin and cloxacillin can be served as the most common drugs of the $\beta$-lactam antibiotics. Elmolla's group reported that the mentioned three kinds of antibiotic wastewater can be degraded via $\mathrm{TiO}_{2}$ under UV light irradiation in the presence of $\mathrm{H}_{2} \mathrm{O}_{2}$ [80]. Results showed that the complete degradation can be fulfilled after $0.5 \mathrm{~h}$ reaction for each pollutant. As a kind of quinolone antibiotics, levofloxacin has received much attention due to it may appeare in the discharged wastewater. Research on photocatalytic degradation of levofloxacin also became popular. For instance, as exhibited in Fig. 2, Gan and co-workers prepared $\mathrm{TiO}_{2}$ via different methods and used for the photocatalytic degradation of levofloxacin. Results showed that the TOC removal rate of the CIP solution used $\mathrm{TiO}_{2}$ (hydr), $\mathrm{TiO}_{2}$ (calc), and $\mathrm{TiO}_{2}$ (hydr + calc) was $76.66 \%, 57.07 \%$, and $28.73 \%$, respectively [81]. Additionally, for the removal of other kinds of drugs like chloramphenicol (a typical kind of chloramphenicol antibiotics), $\mathrm{TiO}_{2}$ also showed a quantitative degradation of the organic molecule after $4 \mathrm{~h}$ of illumination, according to the previous report [82].

However, $\mathrm{TiO}_{2}$ has a wide bandgap, which constrained it from absorb visible light thus only responsible for UV light. As is known to all, UV light only accounts for about $4 \%$ in the overall sunlight spectrum. The drawback limited the industriousness of $\mathrm{TiO}_{2}$ deeply in future applications among antibiotic wastewater degradation. The visible light was occupied exceed to $40 \%$ in the overall sunlight spectrum. As a result, constructing the $\mathrm{TiO}_{2}$ with visible-light-responsible ability could be a possible solving method. In conclusion, element doping was an efficient way. Chen and co-workers reported that the norfloxacin can be degraded under visible light with the C-doped $\mathrm{TiO}_{2}$ [83]. Similarly, N, Ce and P-doped $\mathrm{TiO}_{2}$ were also used for the visible-light-driven antibiotic degradation [84-86].

\subsection{Sulfides and polymeric carbon nitride-based materials}

Other than designing the visible light responsible $\mathrm{TiO}_{2}$-based materials, exploring the novel photocatalysts also
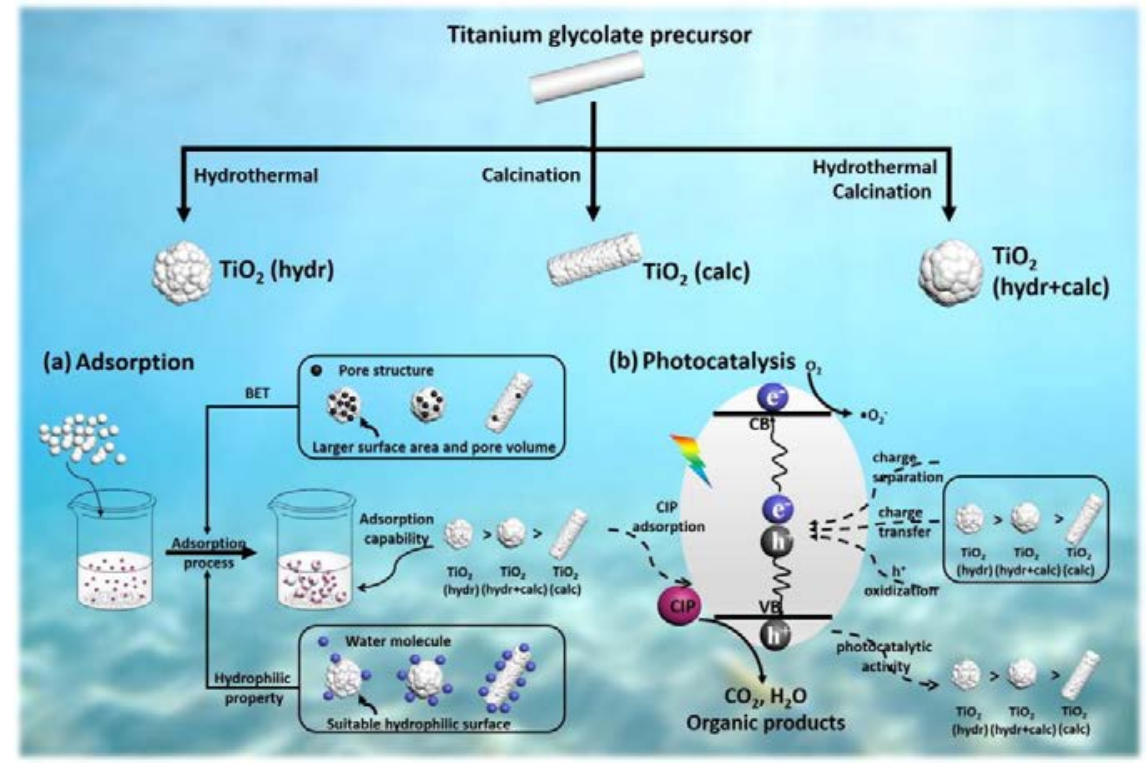

Fig. 2. Photocatalytic ciprofloxacin degradation via $\mathrm{TiO}_{2}$ prepared by different methods. Reprinted with permission from Ref. [81]. Copyright 2014, Elsevier. 
provoked the attentions of scientists. Although the doping strategy could be a possible way to enhance the visible light absorption ability of the photocatalysts, simultaneously, it will decrease the oxidation or reduction ability thermodynamically. This is due to the doping will lead to the decrease of CB position and/or the increase of VB position of the photocatalysts. It was also the reason why the $\mathrm{TiO}_{2}$ with an enhanced visible-light-absorption can be achieved. As a result, it was urgent to explore the novel photocatalysts which can be response to the visible light efficiently.

After being quested for many years, sulfides, like CdS, could be selected as the visible-light-response materials for the removal of the antibiotics under visible light. Many scholars have devoted themselves to the antibiotic's degradation via the sulfides under visible light. CdS was popular in the purification of the tetracyclines wastewater. Vázquez's group reported that tetracycline antibiotic can be degraded via the CdS [71]. The results showed that about $70 \%$ of drugs can be purified after irradiated for $3 \mathrm{~h}$. The mechanisms and performances can be reflected by Fig. 3. Furthermore, the efficiency of the antibiotic degradation could be enhanced by the noble metal doping, like $\mathrm{Ag}$ doped CdS and ZnS, under visible light [87]. The reason could be ascribed to the enhanced surface Plasmon resonance effect. Except for CdS, other sulfides, such as $\mathrm{CuS}, \mathrm{In}_{2} \mathrm{~S}_{3}$ and $\mathrm{Bi}_{2} \mathrm{~S}_{3}$, also have been used for the drugs photodegradation $[75,76,87]$. These results demonstrated that the sulfides could be acted as the efficient photocatalysts in the degradation of antibiotics-contained wastewater.

Polymeric carbon nitride, also was written as PCN or g- $\mathrm{C}_{3} \mathrm{~N}_{4}$, was another kind of materials for visible-light-driven applications. It was reported by Wang and co-workers as well as used in photocatalytic hydrogen evolution initially [26]. It was indicated that the g- $\mathrm{C}_{3} \mathrm{~N}_{4}$ has a bandgap of $\sim 2.7 \mathrm{eV}$, the $\mathrm{CB}$ and VB also can afford the requirement of overall water splitting, as described in Fig. 4, which made it became more popular under the photocatalytic water splitting and hydrogen evolution in the past decades. Simultaneously, g- $\mathrm{C}_{3} \mathrm{~N}_{4}$ also can be used for the photocatalytic degradation of the antibiotic wastewater under visible light. However, due to the negative position thus causing the weak oxidation ability, the pure g- $\mathrm{C}_{3} \mathrm{~N}_{4}$ exhibited a low degradation rate. Therefore, scholars found that constructing the heterojunction between $\mathrm{g}^{-} \mathrm{C}_{3} \mathrm{~N}_{4}$ and other semiconductors could be served as an effective method. For instance, Wang and co-workers synthesized the $\mathrm{Bi}_{3} \mathrm{TaO}_{7}$ quantum dots/g- $\mathrm{C}_{3} \mathrm{~N}_{4}$ nanosheets $0 \mathrm{D} / 2 \mathrm{D}$ Z-scheme composite heterojunction. The photocatalytic performances demonstrated that
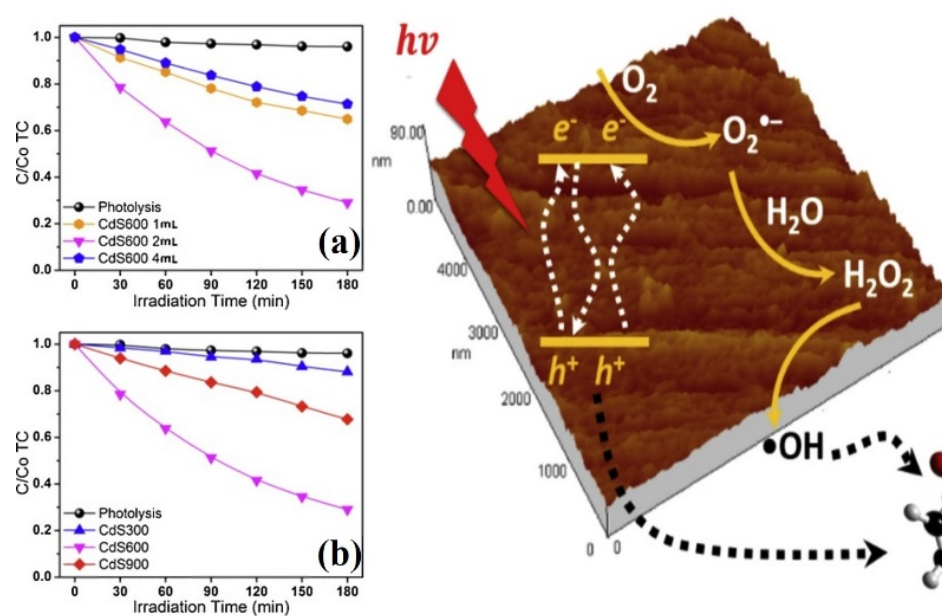

(c)

Fig. 3. Performances and mechanisms of CdS for photocatalytic degradation of tetracycline: (a) starting from different concentrations of the CdS precursors and (b) from different applied voltage as well as (c) illustration of the mechanisms of CdS for degradation of tetracycline. Reprinted with permission from Ref. [71]. Copyright 2016, Elsevier.
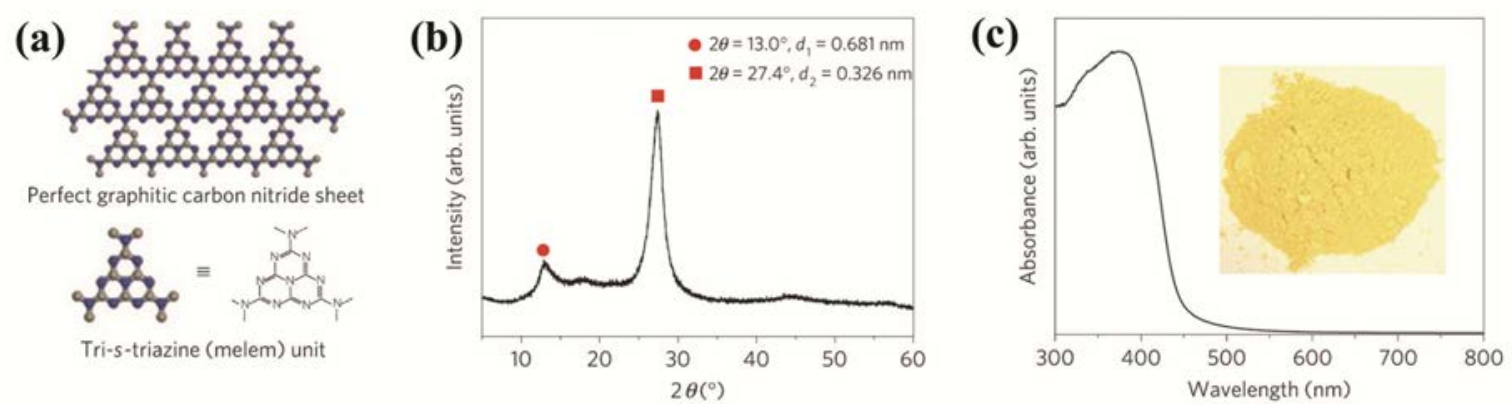

Fig. 4. Crystal structure and optical properties of graphitic carbon nitride: (a) Schematic diagram of a perfect graphitic carbon nitride sheet constructed from melem units, (b) Experimental XRD pattern of the polymeric carbon nitride, revealing a graphitic structure with an interplanar stacking distance of aromatic units of $0.326 \mathrm{~nm}$ and (c) Ultraviolet-visible diffuse reflectance spectrum of the polymeric carbon nitride. Inset: Photograph of the photocatalyst. Reprinted with permission from Ref. [26]. Copyright 2009, Nature Publishing Group. 
the ciprofloxacin can be degraded effectively under visible light. The $80 \% \mathrm{Bi}_{3} \mathrm{TaO}_{7} \mathrm{QD} / 20 \%$ g- $\mathrm{C}_{3} \mathrm{~N}_{4}$ exhibited the highest CIP degradation rate, which is 4 and 12 times faster than the pure $\mathrm{Bi}_{3} \mathrm{TaO}_{7} \mathrm{QD}$ and $\mathrm{g}-\mathrm{C}_{3} \mathrm{~N}_{4}$, respectively [89]. The design of the materials and its photocatalytic results of the ciprofloxacin can be illustrated in Fig. 5. Other semiconductors, like $\mathrm{Nb}_{2} \mathrm{O}_{5}$, $\mathrm{MnFe}_{2} \mathrm{O}_{4}, \mathrm{Ag}_{2} \mathrm{O}, \mathrm{MoS}_{2}, \mathrm{Ag}_{2} \mathrm{CO}_{3}, \mathrm{ZnMoO}_{4}$ and $\mathrm{Ag}_{2} \mathrm{MoO}_{4}$, also can be used for the purification of the tetracycline, $\beta$-lactam and sulfonamide antibiotic wastewater [57,65,66,77,90-92].

\subsection{Bi-contained photocatalysts}

As mentioned above, the sulfides and g- $\mathrm{C}_{3} \mathrm{~N}_{4}$-based materials could be played the role as the visible light responsible materials. However, the more negative position of VB determined that it could no be oxidize $\mathrm{H}_{2} \mathrm{O}$ or $\mathrm{OH}^{-}$to produce $\cdot \mathrm{OH}$ radicals directly, which needs the VB position more negative than 2.38 $\mathrm{eV}$ (vs. NHE, $\mathrm{pH}=0$ ). Therefore, sulfides and $\mathrm{g}-\mathrm{C}_{3} \mathrm{~N}_{4}$ have weak oxidation ability although both of them could absorb the visible light. The presence of $\cdot \mathrm{OH}$ radicals may be mainly relied on the multiple reduction of electrons, which will be facing the energy lost in the process and the production of $\cdot \mathrm{OH}$ radicals will be limited. The degradation process thus may be mainly caused by the holes direct oxidation and less $\cdot \mathrm{OH}$ radicals' oxidation, which exhibited a low degradation rate. In conclusion, to investigate the photocatalysts with both visible-light-responsible ability and a more negative position of VB will be more suitable for the degradation of the antibiotic wastewater degradation.

Under this circumstance, the bismuth-based materials have the potential to be the photocatalysts with high antibiotics degradation in wastewater. Our group has summarized the $\mathrm{CB}$ and VB position of the bismuth-based materials which used traditionally in photocatalysis, as demonstrated in Fig. 6 [93]. The results described that a part of bismuth-based materials could both absorb visible light and afford the thermodynamic requirement for producing $\cdot \mathrm{OH}$ radicals via oxidize water or $\mathrm{OH}^{-}$directly. This special property makes Bi-based materials will be favorable for the degradation of the pollutants under visible light.

Scientist who dedicated to the wastewater treatment has accomplished the investigation of the bismuth-based materials for photocatalytic degradation of the antibiotic. Usually, bis- (a)

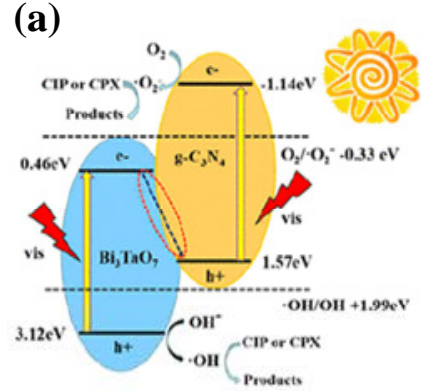

(b)

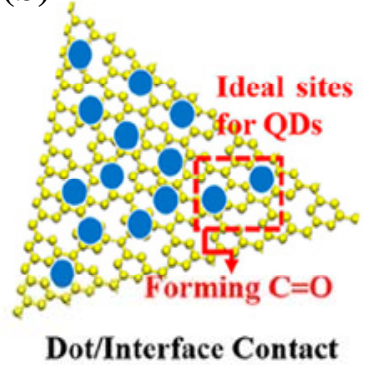

Fig. 5. CIP degradation dynamics curves over the as-prepared samples under visible light irradiation: (a) mechanisms of CIP degradation and (b) the structure of the prepared photocatalysts. Reprinted with permission from Ref. [89]. Copyright 2017, American Chemical Society.

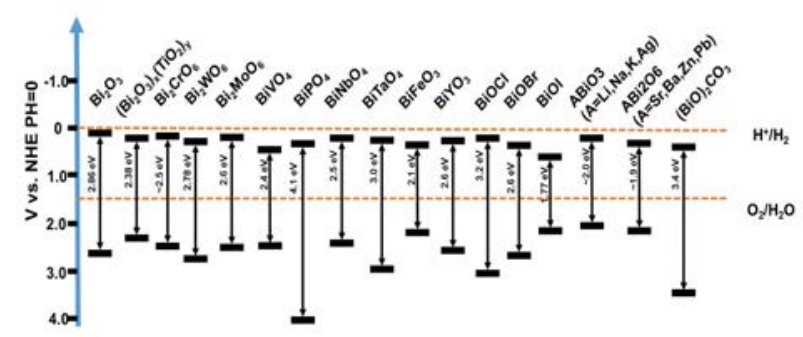

Fig. 6. Band positions of Bismuth-based composite oxides. Reprinted with permission from Ref. [93]. Copyright 2018, Elsevier.

muth-based materials can be mainly classified into four types: $\mathrm{Bi}_{2} \mathrm{O}_{3}, \mathrm{BiVO}_{4}, \mathrm{Bi}_{2} \mathrm{MO}_{6}(\mathrm{M}=\mathrm{W}, \mathrm{Mo})$ and $\mathrm{BiOX}(\mathrm{X}=\mathrm{Cl}, \mathrm{Br}, \mathrm{I})$. For these kinds of photocatalysts, there are many studies concentrated on the removal of the antibiotics. It was reported that hierarchical flower-like $\mathrm{Bi}_{2} \mathrm{O}_{3}$ has been fabricated successfully and applied to the degradation of sulfamethoxazole, as listed in Fig. 7 [94]. The reason can be ascribed to the narrow bandgap of $\mathrm{Bi}_{2} \mathrm{O}_{3}$ and more positive position of $\mathrm{VB}$, which was facilitated to produce $\cdot \mathrm{OH}$ radicals for promoting the removal of sulfamethoxazole. For other sulfonamides, like sulfamethazine, $\mathrm{Bi}_{2} \mathrm{MoO}_{6}$ also could be applied to the degradation process as a photocatalyst [95]. $\mathrm{BiVO}_{4}$ was recommended to have a high visible-light-driven performance in the degradation of ciprofloxacin [96]. Results showed that the rate of $\mathrm{BiVO}_{4}$ was about four times higher than the $\mathrm{P}_{2} 5 \mathrm{TiO}_{2}$ on the degradation of ciprofloxacin. Similarly, BiOBr also can be served as an efficient material for the ciprofloxacin degradation under visible light. Huang's group described the ciprofloxacin degradation was mainly relies on the holes oxidation directly due to the $\cdot \mathrm{OH}$ radicals attack pathway can be excluded [97]. Tang and co-workers reported that norfloxacin can be purified by $\mathrm{Bi}_{2} \mathrm{WO}_{6}$ under visible light. The HPLC-MS results described the pathway of the degradation process, which provided evidences for the elimination of piperazynilic ring in fluoroquinolone molecules by $\cdot \mathrm{OH}$ radicals [98]. The photocatalytic performances and possible degradation pathways of norfloxacin using $\mathrm{Bi}_{2} \mathrm{WO}_{6}$ was proposed and exhibited in Fig. 8.

Compared with the single semiconductors as the photocatalysts, coupling-materials were more popular due to the formation of the heterojunction will be facilitated for the transformation of the photocarries thus beneficial for the enhanced drugs degradation. As a result, a majority of composite photocatalysts, like $\mathrm{NiFe}_{2} \mathrm{O}_{4}$ and $\mathrm{g}-\mathrm{C}_{3} \mathrm{~N}_{4}$ doped $\mathrm{Bi}_{2} \mathrm{O}_{3}$ [49][63], $\mathrm{Cu}_{2} \mathrm{O}, \mathrm{AgI}, \mathrm{Ag}_{2} \mathrm{CO}_{3}, \mathrm{~g}-\mathrm{C}_{3} \mathrm{~N}_{4}$ doped $\mathrm{BiVO}_{4}$ [46][58][62][70], $\mathrm{SnO}_{2}$, $\mathrm{MnNb}_{2} \mathrm{O}_{6}$, g-BN, metallic Bi, $\mathrm{NH}_{2}-\mathrm{MIL}-125$ (Ti), Carbon Quantum Dots, $\mathrm{AgI}, \mathrm{Bi}_{2} \mathrm{O}_{2} \mathrm{CO}_{3}$, iron oxides and $\mathrm{Bi}_{2} \mathrm{O}_{4}$ coupled $\mathrm{BiOX}(\mathrm{X}=\mathrm{Cl}$, $\mathrm{Br}, \mathrm{I})[47] 50,55,56,79,99-[103], \mathrm{ZnO}, \mathrm{g}-\mathrm{C}_{3} \mathrm{~N}_{4}$ doped $\mathrm{Bi}_{2} \mathrm{WO}_{6}$ [78][104], carbon quantum dots doped $\mathrm{Bi}_{2} \mathrm{MoO}_{6}$ [105], as well as $\mathrm{AgI}$ doped $\mathrm{BiOIO}_{3}$ [106], have been synthesized successfully and used for the antibiotic wastewater degradation.

In conclusion, there were mainly four kinds of materials could be used for photocatalytic antibiotic wastewater degradation. All of them both have advantages and limitations. Whether it is suitable for degradation or not was determined by the oxidation potentials of the different types of drugs. We think that the relationship between the VB of photocatalysts 

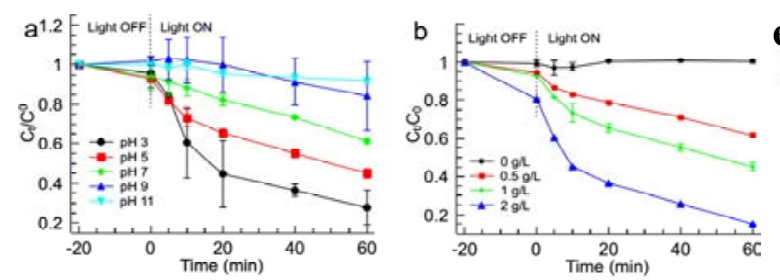

e
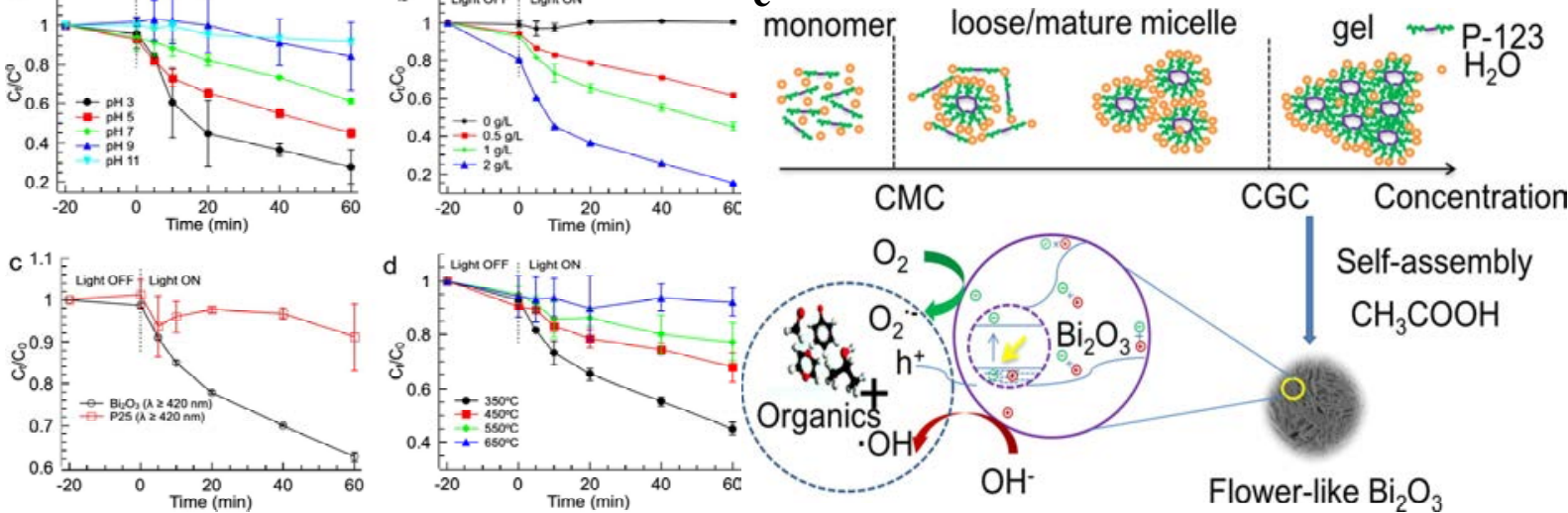

CMC

Self-assembly

$\mathrm{CH}_{3} \mathrm{COOH}$

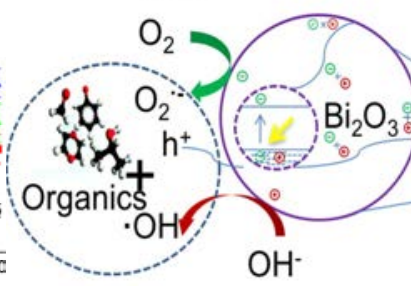

CGC

.

Fig. 7. Design of $\mathrm{Bi}_{2} \mathrm{O}_{3}$ and photocatalytic sulfamethoxazole performances: Effects of $\mathrm{pH}$ (a) and catalyst loading (b) on photochemical degradation of $\mathrm{SMX}$ on flower-like $\mathrm{Bi}_{2} \mathrm{O}_{3}$; (c) degradation of SMX on flower-like $\mathrm{Bi}_{2} \mathrm{O}_{3}$ and $\mathrm{P} 25$ under visible light irradiation; (d) effects of calcination temperature on the photocatalytic performance of $\mathrm{Bi}_{2} \mathrm{O}_{3}$ (the initial concentration of $\mathrm{SMX}$ is $10 \mathrm{mg} \mathrm{L}^{-1}$ ); (e) the preparation of the $\mathrm{Bi}_{2} \mathrm{O}_{3}$ and mechanisms for photocatalytic degradation. Reprinted with permission from Ref. [94]. Copyright 2017, Elsevier.

(a)

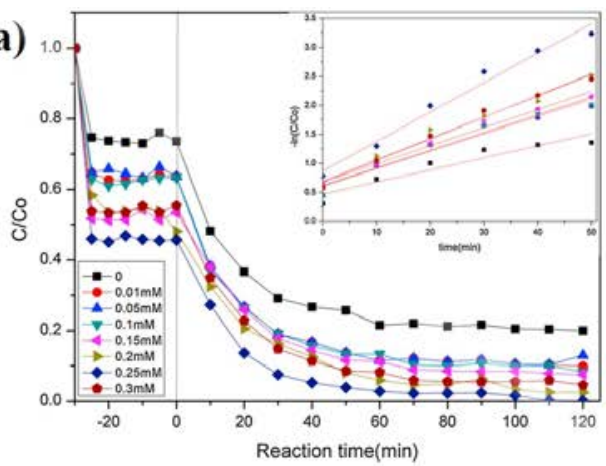

(b)

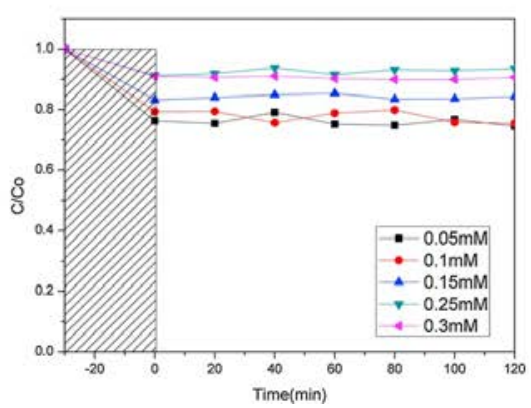

(c)

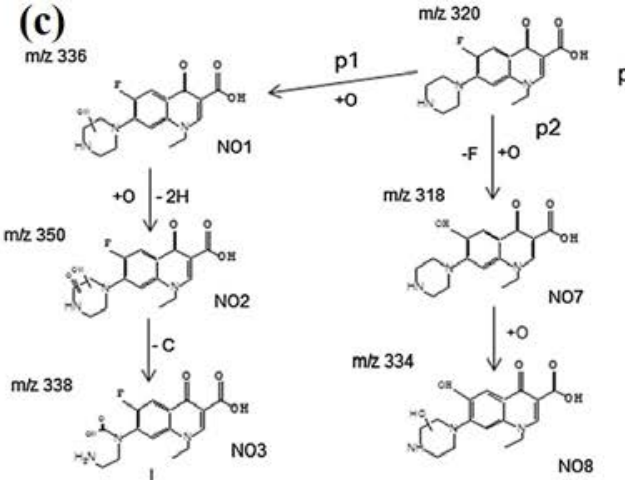

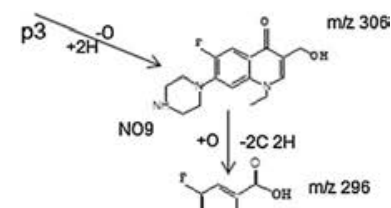

NO8

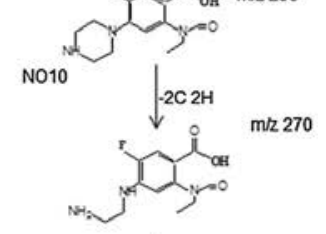

Fig. 8. (a) Photodegradation of $\mathrm{NOF}$ with $\mathrm{Bi}_{2} \mathrm{WO}_{6}$ catalyst under different TX100 concentrations, and first-order fitting curves (inset), (b) Photodegradation of TX100 at different concentrations without NOF by $\mathrm{Bi}_{2} \mathrm{WO}_{6}$ under visible light irradiation at pH 8. Reprinted with permission from Ref. [98] Copyright 2016, Elsevier.

and the oxidation potentials of the antibiotics should play important an important role in the photocatalytic degradation procedure. Furthermore, the $\cdot \mathrm{OH}$ radicals acted as another key issue. It could both originate from holes oxidizing water or $\mathrm{OH}-$ directly and electrons multiple reduction methods.

\section{Photocatalytic hydrogen evolution from antibiotic wastewater}

Hydrogen was clean and green energy which was potential to be a substitute for the fossil energy to solve air pollution. Besides, photocatalytic technology was also an environmentally friendly method. Therefore, in recent decades, studies on hy- drogen energy from photocatalytic overall water splitting have received much attention [107-122]. However, the solar to hydrogen (STH) efficiency was still low in the pure water systems. The rapid recombination of photoelectrons and holes may be an important reason. Therefore, the sacrificial reagents were added to consume the holes and prolong the life of electrons to produce hydrogen. Furthermore, the addition of the sacrificial reagents also will largely decrease the Gibbs free energy of the hydrogen generation reactions, which will beneficial for hydrogen evolution. Consequently, this method was popular due to it can improve the amount of evolved hydrogen largely. A quantum efficiency reached to $100 \%$ has already been proposed [123]. Additionally, a compound parabolic concentrator 
(CPC) for particulate photocatalytic hydrogen evolution has been designed and showed that hydrogen could be obtained with a productivity of 2.9 and $4.0 \mathrm{~L} / \mathrm{h}$ every spring day and summer day of China, respectively [124]. Although these progress of producing hydrogen energy seem steps closer to the industriousness, the cost of the sacrificial reagents will be the hinder factor. Hence, it is necessary to quest for the less expensive sacrificial reagent. The solutions were focused on the pollutants acted as the electrons acceptor.

As discussed aforementioned, antibiotic wastewater was a kind of severe pollutants which was existed in wastewater. Applied antibiotic wastewater to hydrogen energy before it was discharged could be a novel insight in future research. It contains the strategy of waste to energy, which represents the sustainable theory.

Since 2017, there were a few reports used different kinds of antibiotic wastewater to produce hydrogen. As a conclusion, three types of antibiotics have been proved to produce hydrogen via photocatalysis. $\mathrm{Xu}$ and co-workers have found the presence of poisonous macrolide antibiotics in the photocatalytic systems enhanced the $\mathrm{H}_{2}$ yield while itself could be degraded simultaneously under visible light $(\lambda>420 \mathrm{~nm})$, using g- $\mathrm{C}_{3} \mathrm{~N}_{4}$ as the photocatalysts. Roxithromycin, Claricid, Kitasamycin as the model of macrolide antibiotics and the degradation pathways were explored by HPLC-MS, respectively. The performances and degradation pathways can be reflected in Fig. 9. Results of mechanisms exploration illustrated that the macrolide antibiotics player a role of sacrificial agent to consume $\mathrm{H}_{2} \mathrm{O}_{2}$ thus being degraded and simultaneous enhancing of the hydrogen yield [39].

Moreover, Nie et. al. [40] using the $\mathrm{C}_{3} \mathrm{~N}_{4}$-based composite photocatalysts, grapheme quantum dots $/ \mathrm{Mn}-\mathrm{N}-\mathrm{TiO}_{2} / \mathrm{g}-\mathrm{C}_{3} \mathrm{~N}_{4}$ (GQDs/TCN), in a hydrogen evolution and antibiotics wastewater degradation system. The ciprofloxacin, which was a traditional quinolone antibiotic drug, was played the role of the sacrificial reagent in this research. Furthermore, the authors proved that the roles of $\cdot \mathrm{OH}$ radicals were crucial in the procedure of the degradation. The presence of antibiotic wastewater improved the evolved hydrogen amount compared with photocatalytic that in the pure water system. Additionally, the heterojunction between $\mathrm{Mn}-\mathrm{N}-\mathrm{TiO}_{2}$ and $\mathrm{g}-\mathrm{C}_{3} \mathrm{~N}_{4}$ could be responsible for the enhanced photocatalytic performances. The two studies took the macrolide and quinolone antibiotic as the sacrificial reagents in a photocatalytic reduction simultaneous with oxidation systems, respectively. More types of antibiotics also need to be explored. Subsequently, their group constructed another g- $\mathrm{C}_{3} \mathrm{~N}_{4}$-based composite, g- $\mathrm{C}_{3} \mathrm{~N}_{4} /$ Carbon-CdS di-quantum dots, for photocatalytic synchronous hydrogen with tetracycline antibiotic degradation. The results proved that tetracycline antibiotic drugs also could be acted as the sacrificial reagent [41]. Chew's group also chooses the tetracycline antibiotic as the sacrificial agents for photocatalytic hydrogen. The experiment results showed that both hydrogen evolution and tetracycline antibiotic degradation can be performed simultaneously using the $\mathrm{g}-\mathrm{C}_{3} \mathrm{~N}_{4}$ as the photocatalysts, as depicted in Fig. 10 0. Besides the g- $\mathrm{C}_{3} \mathrm{~N}_{4}$-based materials for simultaneous hydrogen production with antibiotics wastewater degradation, other materials also can be utilized to produce hydrogen energy under the tetracycline antibiotic system. Shi's group synthesized the all-solid-state Z-scheme $\mathrm{RGO}-\mathrm{Cu}_{2} \mathrm{O} / \mathrm{Fe}_{2} \mathrm{O}_{3}$ photocatalyst [43]. They selected the tetracycline antibiotic as the sacrificial reagent in their research. As a conclusion, the $\mathrm{H}_{2}$ production using tetracycline over the composite showed eight times and five times higher than that in pure water and methanol systems under the irradiation of visible light $(\lambda>420 \mathrm{~nm})$, respectively. The construction of Z-scheme heterojunction was favorable for the transformation of photocarries. The aforementioned reasons dramatically improved the hydrogen production efficiency.

Our group has initially applied the $\beta$-lactam antibiotic to photocatalytic hydrogen evolution. Amoxicillin, which was a common kind of $\beta$-lactam antibiotic drugs, was selected as the sacrificial reagent to fulfil the strategy of waste to energy under visible light $(\lambda>420 \mathrm{~nm})$ [44]. The $\mathrm{g}-\mathrm{C}_{3} \mathrm{~N}_{4}$ was served as the photocatalysts and further being constructed with metallic bismuth to form Mott-Schottky heterojunction, which will enable the delocalization of electrons between metal and semiconductor and thus beneficial for enhancing photocatalytic

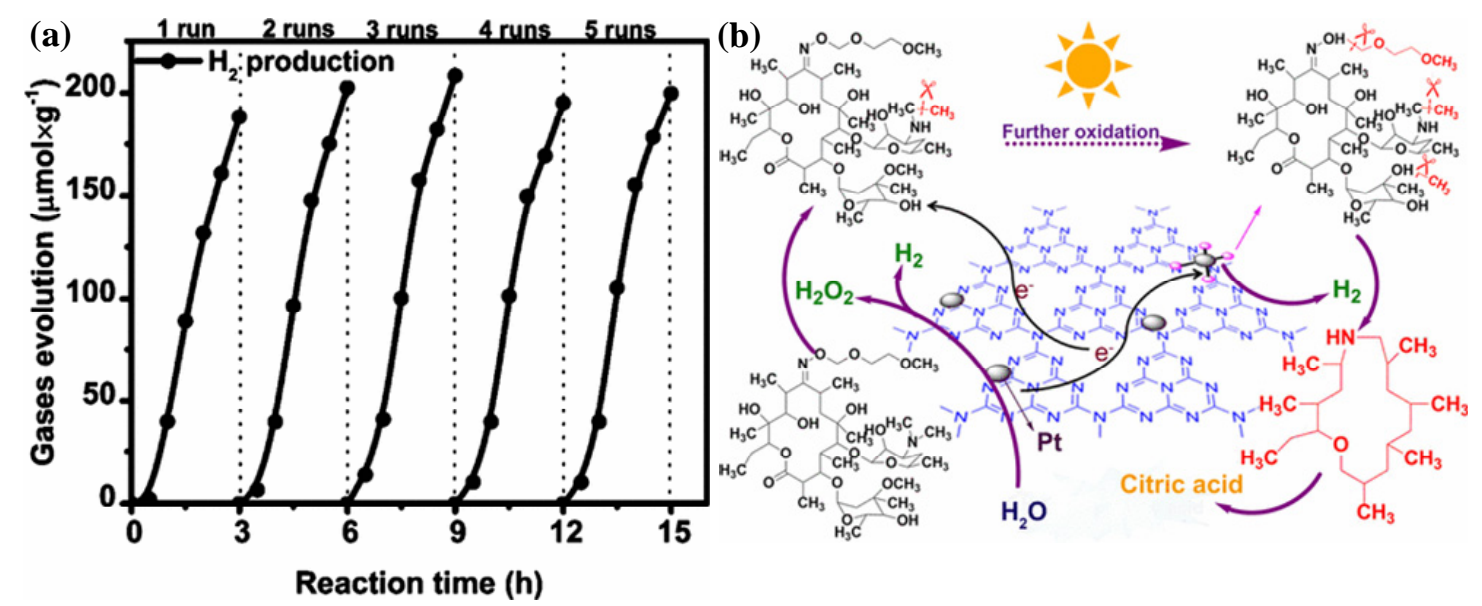

Fig. 9. (a) Recycled photocatalytic hydrogen evolution in the photocatalytic macrolide antibiotics degradation process and (b) the possible degradation pathways of macrolide antibiotics wastewater in a simultaneous system. Reprinted with permission from Ref. [39]. Copyright 2017, American Chemical Society. 

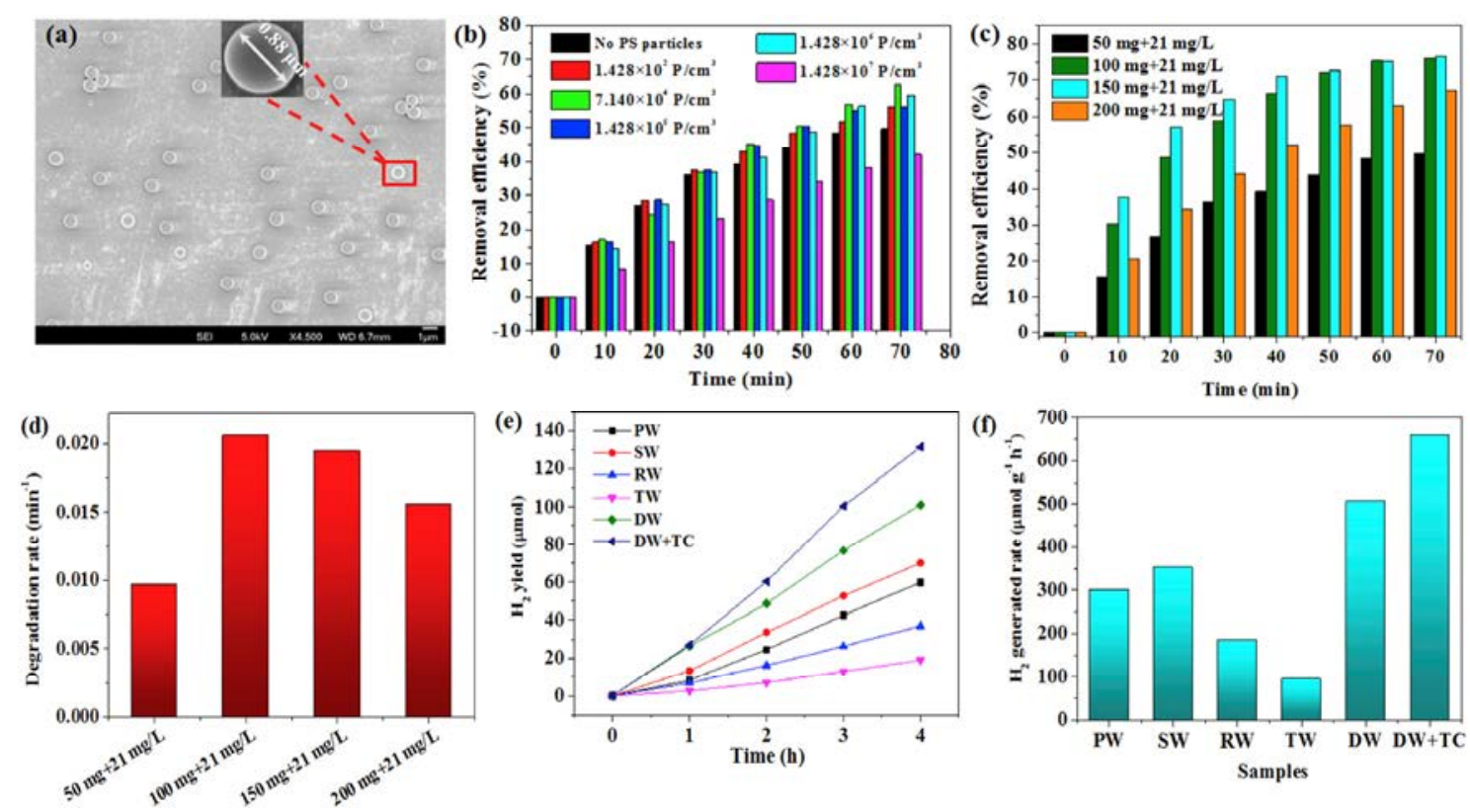

Fig. 10. (a) SEM image of polystyrene (PS) particles; (b) effect of PS particles on the degradation of TC by CNF-4. (c, d) Effect of CNF-4 dosage on removal of TC. Visible-light photocatalytic $\mathrm{H}_{2}$ evolution by CNF-4 from different water matrices: (e) cumulative amount of $\mathrm{H}_{2}$ with time; (f) $\mathrm{H}_{2}$ evolution rate. (PW: Pharmaceutical wastewater; SW: Real seawater; RW: Real reservoir water; TW: Tap water; DW: deionized water; DW + TC: deionized water with the addition of $21 \mathrm{mg} / \mathrm{L} \mathrm{TC}$ ). Reprinted with permission from Ref. 0. Copyright 2018, Elsevier.

performances. The photocatalytic experimental results demonstrated that hydrogen evolution was companied with amoxicillin degradation. The oxidation potential of amoxicillin was tested and the thermodynamics mechanisms indicated that the amoxicillin degradation can be ascribed to the holes direct oxidation. The degradation pathways also determined by the HPLC-MS method. The results also proved the hydrogen evolution simultaneous amoxicillin degradation under visible light.

\section{Conclusions and outlook}

In this mini-review, the photocatalytic degradation and conversion of antibiotics was summarized. Some photocatalytically widely used drugs were concluded and as well as the commonly used photocatalysts were also introduced. In the part of the photocatalytic degradation, $\mathrm{TiO}_{2}$-based materials, bismuth-contained materials, sulfides and g- $\mathrm{C}_{3} \mathrm{~N}_{4}$-based materials were the traditional photocatalysts in the removal of the antibiotics. The photocatalytic hydrogen evolution with simultaneous antibiotic wastewater degradation can be fulfilled. These studies proposed a new insight, which was from the antibiotic wastewater, to produce hydrogen. This is the first time the relative researches were summarized although it was rare.
However, besides more visible light responsible materials also need to be explored, such as black phosphorous, there are also some limitations on the modern development about the photocatalytic degradation and utilization of antibiotics.

(1) In the photocatalytic degradation part, different types of drugs have different oxidization potential. Therefore, the VB position of the photocatalysts is very important because it determines whether the photogenerated holes could oxidize the drugs directly or not. Therefore, the test for oxidation potential of antibiotics will be necessary to clearly illustrate the mechanisms of photocatalytic degradation procedure. Furthermore, the products through holes oxidation directly and the $\cdot \mathrm{OH}$ attack may be different in the photocatalytic degradation process, which also needs further in-depth studies to prove;

(2) There also some limitations in the photocatalytic hydrogen evolution with simultaneous antibiotic wastewater degradation. Firstly, it is important to demonstrate hydrogen sources. Although the antibiotic played the role of sacrificial reagent, however, the hydrogen source is still ambiguous. Whether the antibiotics made contributions is important to prove the insight of the waste to energy. Secondly, the experimental conditions always performed at an anaerobic condition. However, normally, the pollutants can be hardly mineralized

Table 1

Reports on photocatalytic $\mathrm{H}_{2}$ evolution simultaneous with antibiotic degradation.

\begin{tabular}{|c|c|c|c|c|c|c|c|c|}
\hline Catalyst & Co-catalyst & Mass/mg & Antibiotic & Light source & Evolved $\mathrm{H}_{2}$ rate & Degradation rate & Year & Ref. \\
\hline $\mathrm{g}-\mathrm{C}_{3} \mathrm{~N}_{4}$ & $2 \mathrm{wt} \% \mathrm{Pt}$ & 40 & Macrolide & $\lambda>420 \mathrm{~nm}$ & $\sim 17 \mu \mathrm{mol} / \mathrm{h}$ & $100 \%$ & 2017 & [39] \\
\hline $\mathrm{RGO} / \mathrm{Cu}_{2} \mathrm{O} / \mathrm{Fe}_{2} \mathrm{O}_{3}$ & - & 50 & Tetracycline & $\lambda>420 \mathrm{~nm}$ & $0.3 \mu \mathrm{mol} / \mathrm{h}$ & $20 \%$ & 2017 & {$[40]$} \\
\hline CDs/CdS/GCN & $1 \mathrm{wt} \% \mathrm{Pt}$ & 50 & Tetracycline & $\lambda>420 \mathrm{~nm}$ & $0.26 \mu \mathrm{mol} / \mathrm{h}$ & $91 \%$ & 2018 & {$[41]$} \\
\hline GQDs/TCN & $3 w t \% \mathrm{Pt}$ & 45 & Quinolone & $320 \mathrm{~nm} \leq \lambda \leq 780 \mathrm{~nm}$ & $0.045 \mu \mathrm{mol} / \mathrm{h}$ & $89 \%$ & 2018 & 0 \\
\hline g- $\mathrm{C}_{3} \mathrm{~N}_{4}$ foam & - & 50 & Tetracycline & $\lambda>420 \mathrm{~nm}$ & $32.9 \mu \mathrm{mol} / \mathrm{h}$ & - & 2018 & {$[43]$} \\
\hline $\mathrm{Bi} / \mathrm{g}-\mathrm{C}_{3} \mathrm{~N}_{4}$ & $1 \mathrm{wt} \% \mathrm{Pt}$ & 50 & $\beta$-lactam & $\lambda>420 \mathrm{~nm}$ & $35.9 \mu \mathrm{mol} / \mathrm{h}$ & $5.3 \%$ & 2019 & {$[44]$} \\
\hline
\end{tabular}


completely under an anaerobic environment. That determines the photocatalytic hydrogen energy should be performed before the degradation process. Thus, the byproducts under the anaerobic also need to be investigated.

\section{References}

[1] Q. Q. Zhang, G. G. Ying, C. G. Pan, Y. S. Liu, J. L. Zhao, Environ. Sci. Technol., 2015, 49, 6772-6782.

[2] D. Li, W. D. Shi, Chin. J. Catal., 2016, 37, 792-799.

[3] V. K.Sharma, N. Johnson, L. Cizmas, T. J. McDonald, H. Kim, Chemosphere, 2016, 150, 702-714.

[4] N. F. F. Moreira, J. M. Sousa, G. Macedo, A. R. Ribeiro, L. Barreiros, M. Pedrosa, J. L. Faria, M. F. R. Pereira, S. Castro-Silva, M. A. Segundo, C. M. Manaia, O. C. Nunes, A. M. T. Silva, Water Res., 2016, $94,10-22$.

[5] W. Wang, G. Li, T. An, D. K. L. Chan, C. Y. Jimmy, P. K. Wong, Appl. Catal. B, 2018, 238, 126-135.

[6] M. B. Ahmed, J. L. Zhou, H. H. Ngo, W. Guo, N. S. Thomaidis, J. Xu, J. Hazard. Mater., 2017, 323, 274-298.

[7] P. Zhou, J. Yu, M. Jaroniec, Adv. Mater., 2014, 26, 4920-4935.

[8] J. Liu, W. Fang, Z. Wei, Z. Qin, Z. Jiang, W. Shangguan, Appl. Catal. B, 2018, 238, 465-470.

[9] W. Fang, Z. Qin, J. Liu, Z. Wei, Z. Jiang, W. Shangguan, Appl. Catal. $B, 2018,236,140-146$.

[10] J. Liu, W. Fang, Z. Wei, Z. Qin, Z. Jiang, W. Shangguan, Catal. Sci. Technol., 2018, 8, 1375-1382.

[11] Z. Qin, W. Fang, J. Liu, Z. Wei, Z. Jiang, W. Shangguan, Chin. J. Catal, 2018, 39, 472-478.

[12] W. Fang, J. Liu, L. Yu, Jiang, Z. Jiang, W. Shangguan, Appl. Catal. $B$, 2017, 209, 631-636.

[13] Z. Wei, R. Li, R. Wang, RSC Adv., 2018, 8, 7956-7962.

[14] Z. D. Wei, R. Wang, Chin. Chem. Lett., 2016, 27, 769-772.

[15] A. Fujishima, K. Honda, Nature, 1972, 238, 37-38.

[16] R. A. Palominos, M. A. Mondaca, A.Giraldo, G. Peñuela, M. Pérez-Moya, H. D. Mansilla, Catal. Today, 2009, 144, 100-105.

[17] R. Palominos, J. Freer, M. A. Mondaca, H. D. Mansilla, J. Photochem. and Photobiol. A, 2008, 193, 139-145.

[18] F. J. Beltran, A. Aguinaco, J. F. García-Araya, A. Oropesa, Water Res., 2008, 42, 3799-3808.

[19] J. H. O. S. Pereira, A. C. Reis, D. Queirós, O. C. Nunes, M. T. Borges, V. J. P. Vilar, R. A. R. Boaventura, Sci. Total. Environ., 2013, 463, 274-283.
[20] S. K. Kansal, P. Kundu, S. Sood, R. Lamba, A. Umar, S. K. Mehta, New J. Chem., 2014, 38, 3220-3226.

[21] A. Vázquez, D. B. Hernández-Uresti, S. Obregón, Appl. Surf. Sci., 2016, 386, 412-417.

[22] Q. Wang, J. Li, Y. Bai, J. Lian, H. Huang, Z. Li, W. Shangguan, Green Chem., 2014, 16, 2728-2735.

[23] X. Chen, W. Chen, H. Gao, Y. Yang, W. Shangguan, Appl. Catal. $B, \mathbf{2 0 1 4}, 152,68-72$.

[24] S. S. Boxi, S. Paria, RSC Adv., 2014, 4, 37752-37760.

[25] H. Zhang, Y. Zhu, J. Phy. Chem. C, 2010, 114, 5822-5826.

[26] X. Wang, K. Maeda, A. Thomas, K. Takanabe, G. Xin, J. M. Carlsson, M. Antonietti, Nat. Mater., 2009, 8, 76-80.

[27] S. Cao, Y. Li, B. Zhu, M. Jaroniec, J. Yu, J. Catal., 2017, 349, 208-217.

[28] Y. P. Zhu, T. Z. Ren, Z. Y. Yuan, ACS Appl. Mater. Interf., 2015, 7, 16850-16856.

[29] X. Chen, R. Shi, Q. Chen, Z. Zhang, W. Jiang, Y. Zhu, T. Zhang, Nano Energy, 2019, 59, 644-650.

[30] A. Mirzaei, Z. Chen, F. Haghighat, L. Yerushalmi, Appl. Catal. B, 2019, 242, 337-348.

[31] N. Liu, N. Lu, Y. Su, P. Wang, X. Quan, Sep. Purif. Technol,, 2019, 211, 782-789.

[32] W. Yan, L. Yan, C. Jing, Appl. Catal. B, 2019, 244, 475-485.

[33] Z. Wei, J. Liu, W. Fang, Z. Qin, Z. Jiang, W. Shangguan, Catal. Sci. Technol., 2018, 8, 3774-3784.

[34] W. Fang, W. Shangguan, Int. J. Hydrogen Energy, 2018, 44, 895-912.

[35] D. W. Wakerley, M. F. Kuehnel, K. L. Orchard, K. H. Ly, T. E. Rosser, E. Reisner, Nature Energy 2017, 2, 17021.

[36] G. Ji, X. Xu, H. Yang, X. Zhao, X. He, M. Zhao, Environ. Sci. Technol., 2017, 51, 11484-11492.

[37] D. Jiang, X. Chen, Z. Zhang, L. Zhang, Y. Wang, Z. Sun, R. M. Irfan, P. Du, J. Catal., 2018, 357, 147-153.

[38] J. Han, H. Cheng, L. Zhang, H. Fu, J. Chen, Chem. Eng. J., 2018, 335, 231-235.

[39] Z. Xu, S. Xu, N. Li, F. Wu, S. Chen, W. Lu, W. Chen, ACS Sustainable Chem. Eng., 2017, 5, 9667-9672.

[40] Y. C. Nie, F. Yu, L. C. Wang, Q. J. Xing, X. Liu, Y. Pei, J.-P. Zou, W.-L. Dai, Y. Li, S. L. Suib, Appl. Catal. B, 2018, 227, 312-321.

[41] X. H. Jiang, L. C. Wang, F. Yu, Y. C. Nie, Q. J. Xing, X. Liu, Y. Pei, J. P. Zou, W. L. Dai, ACS Sustainable Chem. Eng., 2018, 6, 12695-12705.

[42] H. Wang, Y. Wu, M. Feng, W. Tu, T. Xiao, T. Xiong, H. Ang, X. Yuan, J. W. Chew, Water Res., 2018, 144, 215-225.

\section{Graphical Abstract}

Chin. J. Catal., 2020, 41: 1440-1450 doi: S1872-2067(19)63448-0

A review on photocatalysis in antibiotic wastewater: Pollutant degradation and hydrogen production

Zhidong Wei, Junying Liu, Wenfeng Shangguan*

Shanghai Jiao Tong University

This mini-review concluded the recent development of photocatalysis in antibiotic wastewater, including degradation and regarded it as a kind of energy for producing hydrogen. Furthermore, some challenges and perspectives were also proposed.

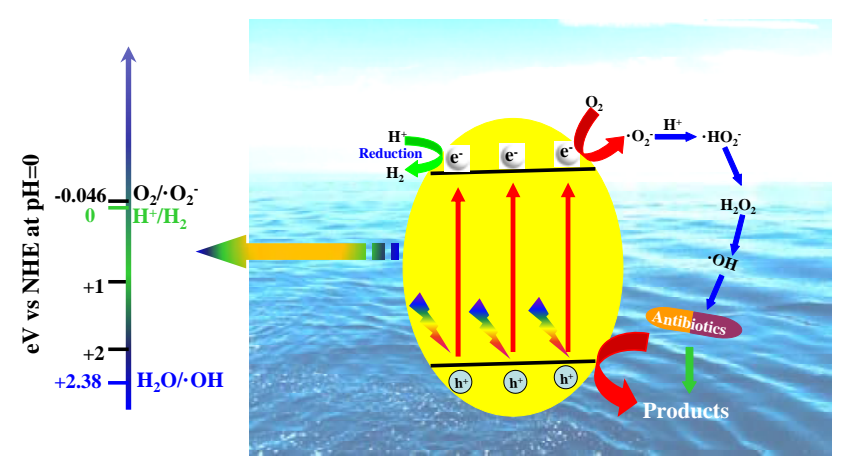


[43] H. Shen, G. Liu, X. Yan, J. Jiang, Y. Hong, M. Yan, B. Mao, D. Li, W. Fan, W. Shi, Mater. Today Energy, 2017, 5, 312-319.

[44] Z. Wei, J. Liu, W. Fang, M. Xu, Z. Qin, Z. Jiang, W. Shangguan, Chem. Eng. J., 2019, 358, 944-954.

[45] Q. Chen, S. Wu, Y. Xin, Chem. Eng. J., 2016, 302, 377-387.

[46] Y. Deng, L. Tang, G. Zeng, C. Feng, H. Dong, J. Wang, H. Feng, Y. Liu, Y. Zhou, Y. Pang, Environ. Sci.: Nano, 2017, 4, 1494-1511.

[47] X. J. Wen, C. G. Niu, L. Zhang, G. M. Zeng, ACS Sustainable Chem. Eng., 2017, 5, 5134-5147.

[48] Y. Gong, Y. Wu, Y. Xu, L. Li, C. Li, X. Liu, L. Niu, Chem. Eng. J., 2018, 350, 257-267.

[49] A. Ren, C. Liu, Y. Hong, W. Shi, S. Lin, P. Li, Chem. Eng. J., 2014, 258, 301-308.

[50] M. Yan, Y. Hua, F. Zhu, W. Gu, J. Jiang, H. Shen, W. Shi, Appl. Catal. B, 2017, 202, 518-527.

[51] W. Wang, J. Fang, S. Shao, M. Lai, C. Lu, Appl. Catal. B, 2017, 217, 57-64.

[52] Y. Xu, J. Liu, M. Xie, L. Jing, H. Xu, X. She, J. Xie, Chem. Eng. J., 2019, 357, 487-497.

[53] M. Ji, Z. Zhang, J. Xia, J. Di, Y. Liu, R. Chen, S. Yin, S. Zhang, H. Li, Chin. Chem. Lett., 2018, 29, 805-810.

[54] P. Ding, J. Di, X. Chen, M. Ji, K. Gu, S. Yin, G. Liu, F. Zhang, J. Xia, H. Li, ACS Sustainable Chem. Eng., 2018, 6, 10229-10240.

[55] Q. Hu, J. Di, B. Wang, M. Ji, Y. Chen, J. Xia, H. Li, Y. Zhao, Appl. Surf. Sci., 2019, 466, 525-534.

[56] J. Di, J. Xia, M. Ji, B. Wang, S. Yin, H. Xu, H. Li, Langmuir, 2016, 32, 2075-2084.

[57] Y. Hong, C. Li, G. Zhang, Y. Meng, B. Yin, Y. Zhao, W. Shi, Chem. Eng. J., 2016, 299, 74-84.

[58] D. Jiang, P. Xiao, L. Shao, D. Li, M. Chen, Ind. Eng. Chem. Res., 2017, 56, 8823-8832.

[59] R. Daghrir, P. Drogui, Environ. Chem. Lett., 2013, 11, 209-227.

[60] B. Luo, D. Xu, D. Li, G. Wu, M. Wu, W. Shi, M. Chen, ACS Appl. Mater. Interf., 2015, 7, 17061-17069.

[61] Z. Zhu, Z. Lu, D. Wang, X. Tang, Y. Yan, W. Shi, Y. Wang, N. Gao, X. Yao, H. Dong, Appl. Catal. B, 2016, 182, 115-122.

[62] F. Chen, Q. Yang, J. Sun, F. Yao, S. Wang, Y. Wang, X. Wang, X. Li, C. Niu, D. Wang, G. Zeng, ACS Appl. Mater. Interf., 2016, 8, 32887-32900.

[63] Y. Hong, C. Li, B. Yin, D. Li, Z. Zhang, B. Mao, W. Fan, W. Gu, W. Shi, Chem. Eng. J., 2018, 338, 137-146.

[64] N. K. R. Eswar, S. A. Singh, G. Madras, Chem. Eng. J., 2018, 332, 757-774

[65] S. Ma, J. Xue, Y. Zhou, Z. Zhang, RSC Adv., 2015, 5, 40000-40006.

[66] X. Lu, Y. Jin, X. Zhang, G. Xu, D. Wang, J. Lv, Z. Zhang, Y. Wu, Dalton Trans., 2016, 45, 15406-15414.

[67] Y. Yan, Y. Wu, Y. Yan, W. Guan, W. Shi, J. Phy. Chem. C, 2013, 117, 20017-20028.

[68] Y. Liu, Q. Yao, X. Wu, T. Chen, Y. Ma, C. N. Ong, J. Xie, Nanoscale, 2016, 8, 10145-10151.

[69] C. Zhou, C. Lai, P. Xu, G. Zeng, D. Huang, Z. Li, C. Zhang, M. Cheng, L. $\mathrm{Hu}, \mathrm{J}$. Wan, F. Chen, W. Xiong, R. Deng, ACS Sustainable Chem. Eng., 2018, 6, 6941-6949.

[70] S. Panneri, P. Ganguly, M. Mohan, B. N. Nair, A. A. P. Mohamed, K. G. Warrier, U. S. Hareesh, ACS Sustainable Chem. Eng., 2017, 5, 1610-1618.

[71] Y. Liu, J. Kong, J. Yuan, W. Zhao, X. Zhu, C. Sun, J. Xie, Chem. Eng. J., 2018, 331, 242-254.

[72] A. Vázquez, D. B. Hernández-Uresti, S. Obregón, Appl. Surf. Sci., 2016, 386, 412-417.

[73] Y. Tang, X. Liu, C. Ma, M. Zhou, P. Huo, L. Yu, J. Pan, W. Shi, Y. Yan, New J. Chem., 2015, 39, 5150-5160.
[74] B. Ji, J. Zhang, C. Zhang, N. Li, T. Zhao, F. Chen, L. Hu, S. Zhang, Z. Wang, ACS Appl. Nano Mater., 2018, 1, 793-799.

[75] Z. Wu, L. Chen, C. Xing, D. Jiang, J. Xie, M. Chen, Dalton Trans., 2013, 42, 12980-12988.

[76] Y. Fang, S. R. Zhu, M. K. Wu, W. N. Zhao, L. Han, J. Solid State Chem., 2018, 266, 205-209.

[77] H. Y. Liu, C. Liang, C. G. Niu, D. W. Huang, Y. B. Du, H. Guo, L. Zhang, Y. Y. Yang, G. M. Zeng, Appl. Surf. Sci., 2019, 475, 421-434.

[78] J. Cheng, Y. Shen, K. Chen, X. Wang, Y. Guo, X. Zhou, R. Bai, Chin. J. Catal., 2018, 39, 810-820.

[79] J. Wang, Z. Zhang, X. Wang, Y. Shen, Y. Guo, P. K. Wong, R. Bai, Chin. J. Catal., 2018, 39, 1792-1803.

[80] E. S. Elmolla, M. Chaudhuri, Desalination, 2010, 252, 46-52.

[81] Y. Gan, Y. Wei, J. Xiong, G. Cheng, Chem. Eng. J., 2018, 349, 1-16.

[82] A. Chatzitakis, C. Berberidou, I. Paspaltsis, G. Kyriakou, T. Sklaviadis, I. Poulios, Water Res., 2008, 42, 386-394.

[83] M. Chen, W. Chu, J. Hazard. Mater., 2012, 219, 183-189.

[84] Y. Chen, K. Liu, J. Hazard. Mater., 2017, 324, 139-150.

[85] V. Vaiano, O. Sacco, D. Sannino, P. Ciambelli, Chem. Eng. J., 2015, 261, 3-8.

[86] X. Feng, P. Wang, J. Hou, J. Qian, Y. Ao, C. Wang, J. Hazard. Mater., 2018, 351, 196-205.

[87] S. S. Boxi, S. Paria, RSC Adv., 2014, 4, 37752-37760.

[88] M. Kamranifar, A. Allahresani, A. Naghizadeh,J. Hazard. Mater., 2019, 366, 545-555.

[89] K. Wang, G. Zhang, J. Li, Y. Li, X. Wu, ACS Appl. Mater. Interf., 2017, 9, 43704-43715.

[90] X. Wang, A. Wang, J. Ma, J. Hazard. Mater., 2017, 336, 81-92.

[91] J. Zhang, X. Mao, W. Xiao, Y. Zhuang, Chin. J. Catal., 2017, 38, 2009-2020.

[92] M. Wu, H. Lv, T. Wang, Z. Ao, H. Sun, C. Wang, T. An, S. Wang, Catal. Today, 2018, 315, 205-212.

[93] W. Fang, W. Shangguan, Inter. J. Hydro. Energy., 2018, 44, 895-912.

[94] Y. Bao, T. T. Lim, Z. Zhong, R. Wang, X. Hu, J. Colloid Interf. Sci., 2017, 505, 489-499.

[95] C. Guo, J. Xu, S. Wang, Y. Zhang, Y. He, X. Li, Catal. Sci. Technol., 2013, 3, 1603-1611.

[96] W. Shi, Y. Yan, X. Yan, Chem. Eng. J., 2013, 215, 740-746.

[97] X. Zhang, R. Li, M. Jia, S. Wang, Y. Huang, C. Chen, Chem. Eng. J., 2015, 274, 290-297.

[98] L. Tang, J. Wang, G. Zeng, Y. Liu, Y. Deng, Y. Zhou, J. Tang, J. Wang, Z. Guo, J. Hazard. Mater., 2016, 306, 295-304.

[99] J. Di, J. Xia, M. Ji, B. Wang, S. Yin, Q. Zhang, Z. Chen, H. Li, Appl. Catal. B, 2016, 183, 254-262.

[100] P. Yan, L. Xu, D. Jiang, H. Li, J. Xia, Q. Zhang, M. Hua, H. Li, Electrochim. Acta, 2018, 259, 873-881.

[101] J. Ding, Z. Dai, F. Qin, H. Zhao, S. Zhao, R. Chen, Appl. Catal. $B, 2017,205,281-291$.

[102] C. Guo, S. Gao, J. Lv, S. Hou, Y. Zhang, J. Xu, Appl. Catal. B, 2017, 205, 68-77.

[103] J. Wang, Z. Zhang, X. Wang, Y. Shen, Y. Guo, P. K. Wong, R. Bai, Chin. J. Catal., 2018, 39, 1792-1803.

[104] H. Che, C. Liu, W. Hu, H. Hu, J. Li, J. Dou, W. Shi, C. Li, H. Dong, Catal. Sci. Technol., 2018, 8, 622-631.

[105] J. Di, J. Xia, M. Ji, H. Li, H. Xu, H. Li, R. Chen, Nanoscale, 2015, 7, 11433-11443.

[106] F. Chen, H. Huang, Y. Zhang, T. Zhang, Chin. Chem. Lett., 2017, 28, 2244-2250.

[107] Z. Wei, J. Liu, W. Fang, Z. Qin, Z. Jiang, W. Shangguan, Int. J. Hydrogen Energy, 2018, 43, 14281-14292.

[108] W. Fang, Z. Jiang, L. Yu, H. Liu, W. Shangguan, C. Terashima, A. 
Fujishima, J. Catal., 2017, 352, 155-159.

[109] Z. Jiang, Z. Huang, W. Guo, W. Shangguan, J. Catal., 2019, 370, 210-223.

[110] H. Liu, J. Yuan, Z. Jiang, W. Shangguan, H. Einaga, Y. Teraoka, J. Mater. Chem., 2011, 21, 16535-16543.

[111] W. Fang, J. Liu, D. Yang, Z. Wei, Z. Jiang, W. Shangguan, ACS Sustainable Chem. Eng., 2017, 5, 6578-6584.

[112] W. Fang, Z. Qin, J. Liu, Z. Wei, Z. Jiang, W. Shangguan, Appl. Catal. $B, \mathbf{2 0 1 8}, 236,140-146$.

[113] L. Yu, W. Fang, J. Liu, Z. Qin, Z. Jiang, W. Shangguan, Int. J. Hydrogen Energy, 2017, 42, 6519-6525.

[114] H. She, Y. Sun, S. Li, J. Huang, L. Wang, G. Zhu, Q. Wang, Appl. Catal. B, 2019, 245, 439-447.

[115] T. Zhao, Z. Xing, Z. Xiu, Z. Li, S. Yang, W. Zhou, ACS Appl. Mater. Interf., 2019, 11, 7104-7111.
[116] Y. Wang, Y. Li, S. Cao, J. Yu, Chin. J. Catal., 2019, 40, 867-874.

[117] N. Xiao, S. Li, S. Liu, B. Xu, Y. Li, Y. Gao, L. Ge, Lu, G. Chin. J. Catal., 2019, 40, 352-361.

[118] A. Wang, D. Dai, S. Li, N. Xiao, B. Xu, Y. Gao, L. Ge, Int. J. Hydrogen Energy, 2019, 44, 8188-8196.

[119] S. Li, L. Wang, Y. Li, L. Zhang, A. Wang, N. Xiao, Y. Gao, N. Li, W. Song, L. Ge, J. Liu, Appl. Catal. B, 2019, 254, 145-155.

[120] B. Xu, Y. Li, Y. Gao, S. Liu, D. Lv, S. Zhao, H. Gao, G. Yang, N. Li, L. Ge, Appl. Catal. B, 2019, 246, 140-148.

[121] T. Takata, K. Domen, ACS Energy Lett., 2019, 4, 542-549.

[122] Z. Wang, C. Li, K. Domen, Chem. Soc. Rev., 2019, 48, 2109-2125

[123] M. Liu, Y. Chen, J. Su, J. Shi, X. Wang, L. Guo, Nat. Energy, 2016, 1, 16151.

[124] F. Cao, Q. Wei, H. Liu, N. Lu, L. Zhao, L. Guo, Renew. Energy, 2018, $121,153-163$

\title{
抗生素废水中的光催化: 污染物降解和产氢综述
}

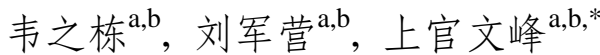 \\ a上海交通大学燃烧与环境技术中心, 上海 200240 \\ b上海交通大学氢科学中心, 上海200240
}

\begin{abstract}
摘要: 近些年来, 关于抗生素药物的研究越来越多. 在1998-2018的20年间, 共计发表了超过5000篇关于抗生素废水处理的 研究论文. 其中, 由于绿色环境友好型的特点, 光催化降解抗生素废水成为一个新的研究热点而备受关注. 本文总结了近 些年来的光催化技术在抗生素废水中应用的研究进展,包括抗生素废水的降解以及转化抗生素废水产氢. 对于常用的催 化剂材料体系也同样进行了讨论. 所涉及到的抗生素主要包含了四种常见的种类, 分别是四环素类, 磺胺类, $\beta$-内酰胺类以 及喹诺酮类抗生素. 此外, 本文还列出了光催化在抗生素废水中的未来发展与挑战的前景, 特别是在光催化转化抗生素废 水制氢方面.

在光催化氧化去除抗生素的研究中, 早期的催化剂体系以 $\mathrm{TiO}_{2}$ 基氧化物体系为主. 然而, 随着研究的深入, $\mathrm{TiO}_{2}$ 基催化 剂材料一般只能响应紫外光, 将极大限制其在未来的工业化应用中. 人们致力于开发新的可响应可见光甚至远红外光的 材料体系. 而硫化物以及氮化物基材料可以满足在可见光实现光催化抗生素废水的降解. 然而, 由于这两类催化剂材料的 价带位置过高, 氧化能力不足, 在可见光下的降解效果也有限. 铋系材料则同时可以解决上述问题, 它们通常具有可见光 吸收能力且价带更正氧化能力更强, 成为可见光光催化降解抗生素催化剂的热门选择之一. 抗生素废水既是一种废物, 也 是一种能源. 光催化抗生素废水制氢的研究近几年来逐渐兴起. 这些研究表明, 可以实现光催化制氢与抗生素废水降解的 同步进行. 目前的研究中, 使用的催化剂材料多集中在 $\mathrm{g}-\mathrm{C}_{3} \mathrm{~N}_{4}$ 以及CdS 体系为主的材料上, 新的材料体系有待于开发.

然而, 对于未来光催化与抗生素废水之间的研究, 还存在着一些问题及挑战. 在光催化降解抗生素中废水中, 抗生素 废水的氧化还原电位需要确定, 这对于催化剂的选择具有一定的指导性. 其次, 新的高效的可见光催化剂材料仍然有待于 开发. 降解的路径与抗生素浓度之间的关系, 也是需要深入研究之所在. 而对于光催化同时产氢去除抗生素废水的体系, 首先是说明氢的来源, 其次在于探索厌氧环境下抗生素废水的降解路径, 自由基迁移转化规律及其协同竞争关系. 最后, 开发新型高效的同时产氢降解抗生素废水的光催化体系依然是一个挑战和难题.
\end{abstract}

关键词: 光催化; 抗生素; 降解; 产氢; 热力学

收稿日期: 2020-01-17. 接受日期: 2020-03-10. 出版日期: 2020-10-05.

*通讯联系人. 电话: (021)34206020; 电子信箱: shangguan@sjtu.edu.cn

基金来源：国家自然科学基金(21773153); 国家重点基础研究发展计划(2018YFB1502001); 上海交通大学氢科学中心的经费支 持.

本文的电子版全文由Elsevier出版社在ScienceDirect上出版(http://www.sciencedirect.com/science/journal/18722067). 